\title{
Investigating the High Turnover of Saudi Nationals versus Non-Nationals in Private Sector Companies Using Selected Antecedents and Consequences of Employee Engagement
}

\author{
Mona N. Moussa ${ }^{1}$ \\ ${ }^{1}$ College of Business Administration, University of Business \& Technology, Saudi Arabia \\ Correspondence: Mona N. Moussa, College of Business Administration, University of Business \& Technology, \\ Jeddah, Saudi Arabia. E-mail: monanmoussa@gmail.com
}

Received: May 2, 2013

Accepted: July 17, 2013

Online Published: August 20, 2013

doi:10.5539/ijbm.v8n18p41

URL: http://dx.doi.org/10.5539/ijbm.v8n18p41

\begin{abstract}
Saudization became inevitable for domestic political stability; however, private organizations are suffering from the high turnover of Saudi nationals and less commitment towards their employers. The researcher set to examine the reasons for the high turnover through examining employee engagement antecedents of the Saudi's nationals versus non-Saudis'. The purpose of this study is to examine selected antecedents and consequences of employee engagement. The researcher distributed surveys among 104 employees working in the healthcare and information technology industries in Saudi Arabia. The results indicate that job characteristics and rewards are the two antecedents that have a positive relationship with employee engagement. Study findings reveal that job characteristics induced employee engagement while reward and recognition induced organizational engagement.
\end{abstract}

Keywords: employee engagement, organizational support, supervisor support, organizational commitment, exchange ideology, job satisfaction, Saudization

\section{Introduction}

Saudi Arabia is over-reliant on migrant and expatriates labor, while their citizens are unemployed. The education system is undergoing fundamental development, with very much imbalance in hiring women. The most unfortunate sector suffering from lack of Saudi nationals is the private sector.

The private sector is suffering from lack of Saudi nationals to work. In fact, these businesses have difficulty in retaining their national Saudi once they are trained. The private sector is offering less pay than the public sector and more demanding in terms of working hours, not to mention the benefits offered by the public sector where $65 \%$ of the labor force is employed. Private sector companies are forced to hire Saudi employees to meet Saudization quota.

The main reason for private sector companies to hire expatriates rather than nationals is that they are paid one third the pay of a national. These companies are seeking to make profit and grow. However, the nationals although well educated they are not well trained. The country is in great need to Saudize their workforce because of the social drawback that exist because of different cultural values between the expats and Saudi citizens, over and above the fear of the sudden migration of expats. Once the Saudization laws are implemented, the country can not guarantee the transfer of knowledge from Expatriates to the local employees (Randeree, 2012).

Saudi Arabia is expanding globally and the need for highly qualified Saudi employees became a necessity. The government is providing jobs, without building on the local employee skills through training. Unfortunately Saudi employees join the force to find themselves in competition with the expatriatess. The fundamental educational system of Whabbi schools, where the curriculum is strictly delivering the fundamentalist view of Islam and far away from involving their generations in creating their own thoughts about competition in a global market place to enhance the economy away from dependence on the oil industry.

Intact Saudi nationals' education is dependent heavily on rote learning religious texts. Saudi students are not encouraged to join classes and courses that develop technical competencies (Dosary \& Rahman, 2005).

Private sector leading companies must be able to train and rehabilitate more nationals from a cost, knowledge and feasibility point of view, which simply means sacrificing profitability. They added that the transitional 
period of training and high turnover of the newly employed Saudis constitute a loss of effectiveness, productivity and their competitive edge in an already very competitive market. Not only do the expatriatess cost less they also bring quality to their work (Fakeeh, 2009).

Private sector companies must make sure to hire nationals and retain them through proper working and healthy conditions. Saudi employees must become engaged in their work to allow private sector companies attain their goals in competing in a global and competitive market. Employee engagement is an intriguing topic which has been researched by many organizations because of its valuable impact on an organization's overall performance and employee affective commitment. Khan (1990) identified employee engagement as when an employee is physically, psychologically and mentally available to the organization while performing their job. There are three important elements for employee engagement, vigor, having mental resilience and high level of energy; dedication, being inspired with a high sense of significance, finally absorption where an employee is happily absorbed into work.

The study of employee engagement has received international recognition worldwide because of the cost of unengaged employees. Rath and Clifton (2004) reported that western economies are losing billions of US dollars each year because of unengaged employees. Similarly, many companies in Saudi Arabia are suffering from the high turnover of Saudi nationals, who are less committed to their employers. Pew Research Center (2011) reported that there is growing number of unemployed Saudi nationals living under the poverty line. Hay Group research (2010) indicated that Saudi employees showed that Saudi nationals are highly motivated when they are encouraged by their supervisors. Unfortunately the organizations are not capitalizing on the Saudi national's enthusiasm. In fact half of the workforce reported that they are neither enabled nor encouraged to put extra effort to get the job done. The study also indicated that 34 percent of Saudi employees are frustrated. Hay research shows that motivated Saudi employees could achieve 4.5 times revenue growth more than their peers if they are motivated to work.

The problem faced by many private sector companies in Saudi Arabia is the flight of competent and qualified Saudi employees from their companies once they become marketable for better offers available in the Saudi market. Although public sector companies are recruiting employees that are neither skilled nor competent to do the job, offering much higher salaries and discretionary benefits, competent Saudi employees would rather work for multinationals for further human resource development. Saudi nationals that prefer the governmental and public sector because of the relaxed working hours and benefits for less skills are not concerned with the developmental process of their skills (AL-Dosary \& Rahman, 2009).

The main aspect of engagement are the antecedents that create it, such as the basic tools to work, proper payment, job satisfaction, job security and above all, clear vision of where the organization is heading. The researcher set out to examine the job and organizational engagement in private sector companies in Saudi Arabia. These companies are suffering from high turnover of Saudi employees and low commitment levels among them. Employment of expatriates became an invisible threat to the domestic political stability (Randeree, 2012). Unfortunately it has become evident for Saudi companies need to restructure the way they are managing their employees in order to prevent young competent Saudis from leaving their jobs.

As the literature review shows in the next section, This study is set to examine the selected antecedents and consequences of employee engagement in private sector companies. According to Hay consulting report (2010), thirty four percent of ineffective and frustrated employees may not have a direct impact on the growth of the economy nowadays; however their frustration and disengagement may lead to less productivity later on as the Saudi economy open up to foreign competition as a result of the (WTO) role.

To determine the main reasons of the high turnover of Saudi nationals in private companies by examining employee engagement towards their jobs and organizations through careful investigation of the different antecedents and consequences of employee engagement Exchange ideology is added to the antecedents which has never been measured in any previous published papers to the best of the researcher knowledge. This study will explain why nationals in the private sector in Saudi Arabia do not relate to their organizations nor to their jobs. The researcher identifies the reasons for failure of employee engagement among the nationals and non-nationals, not only for Saudi companies to be able to compete at an international level but also to successfully recruit nationals to fulfill Saudization requirements.

\section{Literature Review}

\subsection{Employee Engagement}

Employee engagement was first examined by Khan (1990) based on the work of the sociologist Goofman (1961) 
who proposed that employee attachment to their job differs. However Goofman's work was more focused on short-lived encounters rather than long standing attachment to the organization. Diamond and Allcorn (1985) described employee engagement as: "Ongoing, emotionally charged and psychologically complex" (Cited in Khan, 1990, p. 694).

Dynamic environments require engaged employees that are capable of adapting to new surroundings as well as switching easily between activities. These employees are sociable and are characterized as having high activity level. They are also less likely to experience depression and frustration which are the normal characteristics of neurotics. Luthan (2002) recommended researchers to focus on examining "the state like" and not stable like" position, to be able to manage performance. However, many attempts were made to measure whether certain behavioral and personality traits are important for employee engagement.

Manuno et al. (2007) showed that self-efficacy of engaged employees and their optimistic view leads to positive feelings when achieving results for the organization, resulting in what is known as "organizational-based self -esteem, by utilizing a 2 year longitudinal design, the study investigated the antecedents of work engagement among Finnish health care personal $(n=409)$ by distributing questionnaires in 2003 time (1) and 2005 time (2). Study revealed that availability of job resources and organization-based self-esteem proved were the best predictors of work engagement dimensions.

Bakker (2009) found that self-efficacy and optimism over time led to different levels and variation in job and organizational engagement, depending on organizational provision of resources and management effectiveness.

Other studies examined different factors leading to employee engagement include Maslach et al (2001) who concluded through her study on burnout that job characteristics such as feedback and autonomy are considered two important factors to avoid burnout and lead, when applied properly to job engagement. Her model however did not include the concept of exchange ideology.

Researchers, however, realized the importance of reciprocity. Employees with high exchange ideology would reciprocate when they perceive the benefits outweigh the costs. Maslach et al (2001) model proved that employee burnout is the extreme condition of employee engagement; this study did not clarify how individuals may differ in terms of levels of response to these different antecedents, but how they perceive them.

\subsection{Social Exchange Ideology}

Saks (2006) used the theory of social exchange to explain how individuals would differ in their responses according to how they perceive the antecedents, and whether employees will reciprocate with performance. He indicated employees tend to become loyal and trusting over time as long as the organization is fair in applying procedures and resources; the reciprocate relationship between employee and organization is well defined; in other words, employees are willing to give if the organization reciprocates the benefits and resources. There were $\mathrm{N}=102$ employees working at different organizations and in different jobs, average age of 34-60 years old with $60 \%$ female completing the survey. The results showed that perceived organizational support had a significant positive relationship with job and organizational engagement. The study also revealed that job characteristics predicts job engagement while procedural justice predicts organizational engagement.

Kahn (1990) agreed with Robinson et al (2004) that employees become engaged in their work if they receive socio -emotional and economic value for their work, when they do not receive what they expect, they tend to withdraw from their roles and disengage themselves. Reciprocal exchange is measured against the quality of social-economic exchange.

Chen and Francesco (2003) examined the relationship between the three components of organizational commitment continuance commitment, normative commitment and affective commitment and role performance and organizational citizenship behavior in the Republic of China. The researchers took a sample of 253 supervisor and subordinate dyad. The study revealed a significant positive relationship between affective commitment and role performance and organizational citizenship behavior. Results showed that continuance commitment had a negative relationship with organizational citizenship behavior and had no effect on role performance. As for normative commitment; it had a moderate effect on affective commitment and job performance as well as organizational citizenship behavior. Their study also considered exchange ideology in terms of employees' personal attachment to their supervisors as "personalism". Supervisors who show visibility and proximity towards their subordinates through providing timely and constructive feedback, fair rewards and promotions are able to have an impact on their behavior.

According to Cropanzano and Mitchell (2005) study was focused to study four main issues for exchange ideology. The four issues included ambiguities of the theory of exchange ideology, the norms of exchange, the 
resources being exchanged and the social exchange relationships. Results indicated that employees who have high exchange ideology would consider the benefits received by the organization and whether these benefits and resources are worth the dedication and effort or not, thus the reciprocal exchange should be measured with the norm of the quality of social exchange in terms of leadership that may also differ among employees.

Eisenberger et al. (1986) realized that the correlation between perception of organizational support and absenteeism is positively related with employees with high exchange ideology.

\subsection{Antecedents of Employee Engagement}

Koyunca, Burke and Fiksenbaum (2006) examined the different antecedents and consequences of work engagement. Turkish women bankers and the antecedents recognized were reward \& recognition, control and value fit. The survey was collected from $\mathrm{N}=286$ women working in a large Turkish bank with a seventy two percent anonymous completed questionnaires. The aim of this paper was to examine antecedents and consequences of work engagement among professional Turkish bankers. Results showed that the following antecedents such as: rewards and recognition, value fit and control were found to predict all three engagement measures. Vigor predicted psychological well-being outcomes.

Langelaan et al (2006) measured only two personality factors out of five namely-neuroticism and extraversion. The findings of this study indicated that high extraversion and low neuroticism led to more engaged employees. Eisenberger et al. (2001) investigated reciprocations' role in the relationships of perceived organizational support with employees' affective organization commitment and job performance among four hundred and thirteen postal employees that were surveyed.

Chen et al (2002) indicated that supervisors support and feedback can make or break the employees' determination and morale. The researcher conducted two studies, the first was to examine loyalty to supervisor while the second, examined the relationships between loyalty to supervisor, employee performance and organizational commitment.

\subsection{Consequences of Employee}

Witt (1992) study was set to examine the predictors of organizational citizenship behaviors based on perceptions of organizational support, organizational commitment and job satisfaction. The survey included workers at a small tooling plant. The results showed exchange ideology moderated the relationship between organizational support and organizational citizenship behavior. The results showed a similar pattern for OCB (organizational citizenship behavior) and job satisfaction scores. The results of this study matched with previous results of a study conducted previously by Eisenberger et al (1986). Their study confirmed that organizational citizenship behavior is influenced by individuals exchange ideology.

Witt et al. (2001) explored the significant relation between employee satisfaction with adequate training, results indicated that when employees receive proper training adequate and fair support from their supervisors they became effectively committed and engagement. The results of Witt \& Broach, (1993) stated that supervisor support lead to affective commitment. The study included 92 US civilian federal government employees during a two month period. The study investigated the relationship between procedural justice perceptions and satisfaction with training experience. Results indicated that employee with high exchange ideology were more satisfied as trainees unlike trainees with low exchange ideology.

\section{Methodology}

\subsection{Research Questions and Hypotheses}

Khan (1990) indicated that employee engagement model includes job and organizational engagement. Rotherbard, (2001) argued that engagement reflects the psychological involvement of the person. Thus when measuring engagement, one must take into consideration the two roles played by the employee. The two roles are the job the employee is assigned to, while the second role is his/her role towards the organization. This paper addresses the following three questions:

- What is the relationship between the antecedent variables such as job characteristics, rewards and recognition, organizational support; perceived supervisor support, exchange ideology and employee engagement?

- What is the relationship between employee engagement and organizational commitment, intention to quit and job satisfaction as consequences?

- What is the difference in the level of employee job and engagement between Saudi and Non-Saudi employees? 
The above questions are formulated into the following research hypotheses:

H1: There is a significant positive relation between job characteristics and job and organizational engagement.

$\mathrm{H} 2$ : There is a significant relationship between rewards and recognition with job and organizational engagement.

H3: There is a positive significant relation between Perceived supervisor support and job and organizational engagement.

H4: There is a positive significant relationship between Organizational support and employee and organizational engagement.

H5: Strong exchange ideology is significantly negatively related to employee engagement and organizational engagement.

H6: Job and organizational engagement is significantly negatively related to intent to leave and positively related to job satisfaction and organizational commitment.

\subsection{Measures}

The researcher used the model and the surveys of Saks (2006). The following antecedents were used: Job characteristics measured by Hackman and Oldham (1980) six item. As for rewards and recognition a ten-item scale designed specifically for the Saks (2006) was used, and finally The perceived organizational support measured by the adopted SPOS by Rhodes et al (2001) eight-item short form. Organizational commitment was measured using a six-item scale used by Rhodes et al (2001) and intentions to quit three item scale was measured Colarelli's (1984).

\subsection{Procedures and Participants}

One hundred and four participants were included in the study . 39 percent were females and $61 \%$ were males. 87 percent were below the age 35. The survey was completed by both Saudis $60 \%$ and Non Saudis $40 \%$. Front line employee represented $70 \%$ of the participants'. The average years of service was: $46 \%$ spent more than one year in their current jobs. The researcher used a self-administrated method in collecting data. Surveys included demographic information such as; the level of management, gender and nationality.

\subsection{Reliability of Measures}

Survey items were expressed using a five point likert scale with anchors (1) strongly disagree to (5) strongly agree. The reliability of each scale was tested using Chronbach's Alpha reliability coefficient. The scores were refined and Alpha was assessed if each item deleted. Then final short listed items were used for the analysis. Table 1 shows the results of this process.

\subsubsection{Outcome Variables}

Job engagement was measured using a five-item scale, the reliability of this scale was $(\alpha=0.7)$ and after deleting one item the reliability increased to $(\alpha=0.76)$. Organization engagement was evaluated using six-item scale the reliability was $(\alpha=0.88)$ after removing one item the reliability improved ( $\alpha=0.92)$.

\subsubsection{Antecedents of Engagement}

Job characteristics was measured by eight-item scale, after discarding one item the reliability became $(\alpha=0.86)$. The perceived organization support, the perceived supervisor support, and the employee exchange ideology scales were developed. The Chronbach alpha for each scale after deleting the items with low reliability were $(\alpha$ $=0.89,0.93,0.74)$ respectively. Reward and recognition were measured using ten-item score $(\alpha=0.89)$.

\subsubsection{Consequence of Employee Engagement}

The reliability coefficient of the three item scale to measure job satisfaction was $(\alpha=0.83)$ and increased to $(\alpha=$ $0.87)$ after deleting the item number three. Organizational commitment was measured by six-item scale that shows very high reliability $(\alpha=0.95)$. The intention to quit four-item scale shows $(\alpha=0.82)$ and after deleting the last item the reliability jumped to $(\alpha=0.93)$.

\section{Results}

Table 1 presents the scales' items, the mean scores, the standard deviations (SD), the range of each score used in the analysis and the reliability coefficient before and after deleting the items. All the scores showed acceptable reliability (Chronbach $\alpha>0.70$ ). 
Table 1. Descriptive statistics for the scores and their reliability analysis

\begin{tabular}{|c|c|c|c|c|c|}
\hline & Items & $\begin{array}{c}\text { Reliability } \\
\text { Alpha }\end{array}$ & $\begin{array}{l}\text { if items } \\
\text { deleted }\end{array}$ & $\begin{array}{l}\text { Mean } \\
(\mathrm{SD})\end{array}$ & $\begin{array}{c}\text { Reliability } \\
\text { Alpha }\end{array}$ \\
\hline Job engagement & $\begin{array}{l}\text { 1- I really "throw myself into the job } \\
\text { 2- Sometimes I am so into my job that I lose track of } \\
\text { time } \\
\text { 3- This job is all consuming: I am totally into it. } \\
\text { 4- My mind often wanders and I think of other things } \\
\text { when doing my job } \\
\text { 5- I am highly engaged in this job }\end{array}$ & 0.70 & Item No 4 & $3.9(0.7)$ & 0.76 \\
\hline $\begin{array}{l}\text { Organization } \\
\text { engagement }\end{array}$ & $\begin{array}{l}\text { 1-Being a member of this organization is very } \\
\text { captivating } \\
\text { 2-One of the most exciting things for me is getting } \\
\text { involved with things in this organization } \\
\text { 3-I am really not into the "goings-on" in this } \\
\text { organization } \\
\text { 4-Being a member of this organization make me } \\
\text { come "alive" } \\
5 \text { - Being a member of this organization is (exhilarating) } \\
\text { exciting for me } \\
\text { 6-I am highly engaged in this organization }\end{array}$ & 0.88 & Item No 3 & $3.7(0.9)$ & 0.92 \\
\hline Job characteristics & $\begin{array}{l}\text { 1-Your job enjoys a great degree of autonomy } \\
\text { 2-Your job allows you for job significance, A job that } \\
\text { has an obvious beginning and end } \\
\text { 3-Some parts are finished by other people or by } \\
\text { machines } \\
\text { 4- There is variety of skills used in your job } \\
\text { 5-Your job is very much significant( it has an impact on } \\
\text { the lives of other people } \\
\text { 6-Your managers give you feedback on your work } \\
\text { 7-Your co-workers give you feedback on your work } \\
\text { 8-Working on the job allows you to develop } \\
\text { information on how to perform the job }\end{array}$ & 0.77 & $\begin{array}{c}\text { Item No. } \\
3\end{array}$ & $3.5(0.8)$ & 0.86 \\
\hline $\begin{array}{c}\text { Perceived } \\
\text { Organizational } \\
\text { support }\end{array}$ & $\begin{array}{l}\text { 1-My organization really cares about my well-being } \\
\text { 2-My organization strongly considers my goals and } \\
\text { values } \\
\text { 3-My organization shows little concern for me (R) } \\
\text { 4-My organization cares about my opinions } \\
\text { 5-My organization is willing to help me if I need a } \\
\text { special favor } \\
\text { 6-Help is available from my organization when I have a } \\
\text { problem } \\
\text { 7-My organization would forgive an honest mistake on } \\
\text { my part } \\
\text { 8-My organization would take advantage of me, if } \\
\text { given the opportunity ( R) }\end{array}$ & 0.77 & $\begin{array}{l}\text { Items No } \\
3 \& 8\end{array}$ & $3.2(0.8)$ & 0.89 \\
\hline $\begin{array}{c}\text { Perceived supervisor } \\
\text { support }\end{array}$ & $\begin{array}{l}\text { 1-My supervisor cares about my opinion } \\
\text { 2-My supervisors cares about my well-being } \\
\text { 3-My supervisor values my goals and values } \\
\text { 4-My supervisor shows very little care for me (R) }\end{array}$ & 078 & Item No 4 & $3.6(0.9)$ & 0.93 \\
\hline $\begin{array}{l}\text { Reward and } \\
\text { recognition }\end{array}$ & $\begin{array}{l}\text { 1-You are given pay raise } \\
\text { 2-You are guaranteed job security } \\
\text { 3-You are rewarded with a promotion } \\
\text { 4-You enjoy more freedom and opportunities } \\
\text { 5-Your colleagues respect you } \\
\text { 6-Your supervisors praises you on your work }\end{array}$ & 0.89 & NA & $3.1(0.9)$ & 0.89 \\
\hline
\end{tabular}




\begin{tabular}{|c|c|c|c|c|c|}
\hline & $\begin{array}{l}\text { 7-You are offered training \& development } \\
\text { opportunities } \\
\text { 8-You are challenged with more challenging work } \\
\text { assignments } \\
\text { 9-Your organization recognizes their employees in } \\
\text { different forms. } \\
\text { 10-Your organization rewards your employees with a } \\
\text { token of appreciation (e.g. lunch) }\end{array}$ & & & & \\
\hline $\begin{array}{c}\text { Employee exchange } \\
\text { ideology }\end{array}$ & $\begin{array}{l}\text { 1-Employees care towards their organizations should be } \\
\text { displayed if organizations display the same concern and } \\
\text { care towards their employees. } \\
\text { 2- Employees should go an extra mile to help their } \\
\text { organization if their organizations goes an extra mile } \\
\text { for their employees. } \\
\text { 3-Employees should be totally dedicated towards their } \\
\text { organizations, regardless of what their organizations } \\
\text { think of their efforts(R) } \\
\text { 4-Employees should exert effort regardless of whether } \\
\text { the organization appreciates their work or not. (R) } \\
\text { 5-Employees' treated inadequately by a company } \\
\text { should exert less effort } \\
\text { 6- Employees' work hard work should rely partially on } \\
\text { how well the organization is willing to deal their } \\
\text { desires and concerns } \\
\text { 7- Employees' should work hard when their hard work } \\
\text { is rewarded with lead to an increase, or benefits } \\
\text { 8- Employees' work effort ought not to rely on the } \\
\text { equity of the employee pay (R) }\end{array}$ & 0.71 & Item No 5 & $2.7(0.7)$ & 0.74 \\
\hline Job satisfaction & $\begin{array}{l}\text { 1-I am overall satisfied with my job. } \\
\text { 2-I generally like working here } \\
\text { 3-I generally not like my job }\end{array}$ & 0.83 & Item No 3 & $3.5(0.9)$ & 0.87 \\
\hline $\begin{array}{l}\text { Organization } \\
\text { commitment }\end{array}$ & $\begin{array}{l}\text { 1-I am more than satisfied to work at my organization } \\
\text { until I retire } \\
\text { 2-I am committed to work in the organization because } \\
\text { of what it means to me } \\
\text { 3-The organizations problems are my problems } \\
\text { 4-I have strong feelings towards my organization } \\
\text { 5-I am proud to say to others I work at my organization } \\
\text { 6-I feel strong sense of belonging to my organization }\end{array}$ & 0.95 & NA & $3.4(1.1)$ & 0.95 \\
\hline Intention to quit & $\begin{array}{l}\text { 1-I often think of leaving my job } \\
\text { 2-I am planning to look for a new job during the next } \\
12 \text { months } \\
\text { 3-If I am allowed to do it my way, I will be committed } \\
\text { to work for this organization one year from now ( } R)\end{array}$ & 0.82 & Item No 3 & $3.0(1.3)$ & 0.93 \\
\hline
\end{tabular}

Source: Surveys Alan M. Saks, (2006). Antecedents and consequences of employee engagement.

Table 2 presents the inter-correlation of the study variables. It shows that there is a moderate correlation between the job engagement and organization engagement $(\mathrm{r}=0.58 \mathrm{P}<0.001)$. However, the results of paired t-test indicate that while the two measures are correlated and significantly different with higher job engagement participants $($ Mean=3.9) than organization engagement (Mean=3.7). All antecedents were correlated to job and organizational engagement. Perceived organizational support, perceived supervisor support and reward and recognition were significantly positively correlated to engagement measures. Employee exchange ideology was significantly negatively correlated to job and organization engagement. 
Table 2. Inter-correlation matrix of scores

\begin{tabular}{|c|c|c|c|c|c|c|c|c|c|c|}
\hline & 1 & 2 & 3 & 4 & 5 & 6 & 7 & 8 & 9 & 10 \\
\hline 1-Job Engagement & 1 & & & & & & & & & \\
\hline 2- Organization Engagement & $.578^{* *}$ & 1 & & & & & & & & \\
\hline 3- Job characteristics & $.532^{* *}$ & $.497^{* *}$ & 1 & & & & & & & \\
\hline 4- Perceived organizational support & $.331^{* *}$ & $.510^{* *}$ & $.516^{* *}$ & 1 & & & & & & \\
\hline 5- supervisor support & $.371^{* *}$ & $.516^{* *}$ & $.603^{* *}$ & $.579^{* *}$ & 1 & & & & & \\
\hline 6- Reward and recognition & $.453^{* *}$ & $.567^{* *}$ & $.604^{* *}$ & $.741^{* *}$ & $.596^{* *}$ & 1 & & & & \\
\hline 7-Exchange ideology & $-.371^{* *}$ & $-.342^{* *}$ & $-.335^{* *}$ & $-.327^{* *}$ & $-.395^{* *}$ & $-.287^{* *}$ & 1 & & & \\
\hline 8- Organizational commitment & $.572^{* *}$ & $.749^{* *}$ & $.666^{* *}$ & $.631^{* *}$ & $.559^{* *}$ & $.724^{* *}$ & $-.459^{* *}$ & 1 & & \\
\hline 9- Job satisfaction & $.453^{* *}$ & $.626^{* *}$ & $.668^{* *}$ & $.607^{* *}$ & $.554^{* *}$ & $.643^{* *}$ & $-.381^{* *}$ & $.749^{* *}$ & 1 & \\
\hline 10- Intention to quit & $-.413^{* *}$ & $-.632^{* *}$ & $-.498^{* *}$ & $-.567^{* *}$ & $-.459^{* *}$ & $-.599^{* *}$ & $.431^{* *}$ & $-.755^{* *}$ & $-.709^{* *}$ & 1 \\
\hline
\end{tabular}

Table 3. Comparison between the level of engagement and other antecedents and consequences scores between Saudis and non Saudis

\begin{tabular}{lcc}
\hline & Saudi & Non-Saudi \\
\hline Job engagement** & 3.7 & 4.0 \\
Organization engagement* & 3.5 & 3.9 \\
Job characteristics* & 3.3 & 3.7 \\
Perceived organizational support*** & 2.9 & 3.6 \\
Perceived Supervisor support** & 3.4 & 3.8 \\
Reward and recognition*** & 2.8 & 3.5 \\
Exchange ideology*** & 2.9 & 2.5 \\
Job satisfaction** & 3.3 & 3.7 \\
Organizational commitment*** & 3.1 & 3.7 \\
Intention to quit** & 3.3 & 2.6 \\
\hline
\end{tabular}

$* \mathrm{P}<0.05, * * \mathrm{P}<0.01, * * * \mathrm{P}<0.001$.

Table 3 shows that Saudis and non Saudis have statistically significant different scores in all the antecedents and consequences of engagements. Saudis have lower job and organizational engagement than non Saudis. They have lower job characteristics and they perceived the organizational and supervisor support less than non nationals. Saudis have also lower reward and recognition, job satisfaction and organizational commitment. Saudis have more intention to quit and they have more exchange ideology than the non Saudis.

\subsection{Antecedents of Employee Engagement}

Multiple linear regression analysis was conducted to test all the measures of engagement simultaneously. Two regression models were built, one for the predictors of job engagement and another for the predictors of organization engagement. The standardized $\beta$ coefficients for both models are reported in table 4 . The antecedents explained $35 \%$ of the variance in job engagement and $40 \%$ of the variance in organizational engagement $(\mathrm{R} 2=0.35, \mathrm{P}<0.001)$ and $(\mathrm{R} 2=0.40, \mathrm{P}<0.001)$ respectively.

As regard to job engagement model, Job characteristics and reward and recognition were the significant predictors $(\beta=0.38, \mathrm{P}<0.001)$ and $(\beta=0.27, \mathrm{P}<0.05)$. Reward and recognition was a significant predictor of organization engagement $(\beta=0.28, \mathrm{P}<0.05)$.

In controlling for the antecedents of job engagement, there was no significant difference between Saudis and non Saudis in the job engagement and organization engagement. 
Table 4. Multivariate linear regression results

\begin{tabular}{lcc}
\hline & Job engagement & Organization engagement \\
\hline Citizenship & & \\
(Saudis=0 Non-Saudis=1) & 0.04 & -0.06 \\
Job characteristics & $0.38^{* * *}$ & 0.14 \\
Perceived organizational support & -0.12 & 0.12 \\
Supervisor support & -0.03 & 0.15 \\
Reward and recognition & $0.26^{*}$ & $0.29^{*}$ \\
Exchange ideology & -0.21 & -0.13 \\
$\mathrm{R}^{2}$ & 0.35 & 0.40 \\
$\mathrm{~F}$ & $12.58^{* * *}$ & $15.6^{* * *}$ \\
\hline
\end{tabular}

$* \mathrm{P}<0.05,{ }^{* *} \mathrm{P}<0.01,{ }^{* * *} \mathrm{P}<0.001$ values in table are standardized $\beta$ coefficient.

\subsection{Consequences of Employee Engagement}

Three multiple linear regression models were built to regress the outcome on job and organization engagement. Table 5 shows that the engagement scores explained a significant amount of the variance in job satisfaction $\left(\mathrm{R}^{2}\right.$ $=0.41, \mathrm{P}<0.001)$, organizational commitment $\left(\mathrm{R}^{2}=0.59, \mathrm{P}<0.001\right)$, and intention to quit $\left(\mathrm{R}^{2}=0.40, \mathrm{P}\right.$ $<0.001)$.

As regard the job satisfaction model, organization engagement was a significant predictor for job satisfaction $(\beta=0.55, P<0.001)$. In the organizational commitment model, job engagement and organizational engagement predict the commitment to organization $(\beta=0.21, \mathrm{P}<0.01)$, and $(\beta=0.63, \mathrm{P}<0.001)$ respectively. As regard the intention to quit model, the organizational engagement was the significant predictor for quitting $(\beta=0.59, \mathrm{P}<$ $0.001)$

In controlling for job and organization engagement, Non Saudis showed higher organization commitment than Saudis $(\beta=0.13, \mathrm{P}<0.05)$. Non nationals had less intention to quit than national $(\beta=-0.13, \mathrm{P}<0.05)$.

Table 5. Multiple regression results of employee engagement

\begin{tabular}{cccc}
\hline & Job satisfaction & Organizational commitment & Intention to quit \\
\hline Citizenship (Saudis=0 Non-Saudis=1) & 0.07 & $0.13^{*}$ & $-0.13^{*}$ \\
Job engagement & 0.13 & $0.19^{* *}$ & -0.0 \\
Organization engagement & $0.54^{* * *}$ & $0.61 * * *$ & $-0.58^{* * *}$ \\
$\mathrm{R}^{2}$ & 0.41 & 0.61 & 0.42 \\
$\mathrm{~F}$ & $32.49^{* * *}$ & $72.50 * * *$ & $34.03^{* * *}$ \\
\hline
\end{tabular}

$* \mathrm{P}<0.05,{ }^{* *} \mathrm{P}<0.01,{ }^{* * *} \mathrm{P}<0.001$ values in table are standardized $\beta$ coefficient.

\section{Discussion and Implications}

The objective of this study was to investigate the main reasons for Saudi nationals' high turnover working in private sector companies in Saudi Arabia. The study examined only four antecedents; job characteristics, organizational support, reward and recognition, supervisor support along with exchange ideology as an antecedent, excluding procedural and distribution justice from the model.

The researcher found that job characteristics with job engagement are positively correlated, and rewards and recognition with organizational engagement. The practical implication of these findings is that, senior management must redesign the jobs to allow their employees to find pride in their jobs by providing autonomy, task significance, identity, and constructive feedback to match current skills and qualifications of the young Saudi nationals and as the employees are trained and developed.

The study reveals that Saudi nationals are more engaged and have a good sense of appreciation and gratitude when supervisors provide support to them. The results show that Saudi nationals are more inclined to leave their organizations then non-nationals because of lack of organizational support in developing the skills. Management should invest more resources in training and coaching supervisors to value their employees well.

The researcher found supervisor support and perceived organizational support had a negative relationship with 
job engagement. This only indicates that perceive organizational support and supervisor support are considered insignificant in these organizations.

Although table 3 reveals that Saudi nationals have a higher exchange ideology than non-nationals, the higher the exchange ideology the less engaged the employee belongs to the job or organization. The practical implication of these findings is that, employees working in organizations in Saudi Arabia do not relate to their jobs mainly according to the social exchange theory, where the reciprocal relationship is evident.

Management should not underestimate the power of employee's desire for better rewards and recognition, the study reveals that when rewards are not fair or appropriate they become less engaged leading to less committed employees and a higher level and intent to leave the job. The results show that non-nationals are less engaged than nationals when it comes to rewards and recognition.

Study findings show that employee engagement is not grounded on exchange ideology (social exchange theory). In practice, the results suggest that organizations should provide employees with better jobs designed and fair rewards and recognition.

The results for second research question (table 5) examining the relationship between employee engagement and outcome variable such as organizational commitment, intention to leave and job satisfaction showed that; there was a positive relation between job and organizational engagement with organizational commitment and a negative relation with intentions to quit. This has a management implication, since the table reveals high levels of engagement towards the organization would lead to high levels of affective commitment and job satisfaction and lower levels of intention to leave.

The findings indicate that rewards and recognition is the antecedent that promotes employee engagement towards their organization, while job characteristics promote employee engagement towards their job.

Results for the third research question. Table 4 shows that nationals are less engaged to their jobs and organizations; therefore they are less committed to their work and more inclined to leave their jobs than non-nationals. Table 3 indicates the difference between the nationals and non-nationals according to the antecedents proposed in this study. Nationals have a higher intention to leave the organization than non-nationals and are less committed towards their organizations.

\subsection{Limitations and Future Research}

The limitations of this study were summed by the following: the data collected at one point in time; therefore, we cannot generalize the results over a wider population. Future studies could identify other antecedents of employee engagement. This may include the human development, difference in gender, age diversity, and level of education. Future research should be directed to measure other factors that may contribute to failure of Saudization such as measuring the difference between nationals educated in Saudi Arabia and others educated with different educational systems. Finally examine the different factors that led to higher commitment of Saudi women towards their jobs and organizations and less commitment of the Saudi men to the same jobs and organizations.

\subsection{Conclusion}

The success of Saudization in addition to developing the skills of the Saudi nationals became inevitable to meet international standards became inevitable, to accelerate the process and would increase the probability of success for these companies. Private sector companies must employ nationals in front line positions to ascend the promotional ladder. These jobs allow the nationals to become familiar with the nature of these jobs and develop their competencies. Compensation structures should match the development of competencies and workload as many companies are inclined to add tasks to employees without further compensation for their efforts, or simply do not evaluate the employees fairly and consequently, compensation does not reflect the true efforts exerted for the job.

Managers play a pivotal role in developing highly effective and working environments for their employees. Their main focus must be on developing a positive employee perception of organizational support through procedural and distributive justice. Their role is to allow employees to have the freedom to suggest and promote the working process to achieve a competitive advantage.

Finally, employees must realize the importance of contributing to the organization, and to ensure this process, organizations must be able to meet the demands of the employees .Private organizations must be able to compete on international basis with a highly committed workforce that is engaged with their job and organization. 


\section{References}

Adel, S. Al. D., \& Syed, M. R. (2005). Saudization (Localization)-A critical Review. Human Resource Development International, 8(4), 495-502. http://dx.doi.org/10.1080/13678860500289534

Alan, M., \& Saks. (2006). Antecedents and consequences of employee engagement. Journal of Managerial Psychology, 21(7), 600-619. http://dx.doi.org/10.1108/02683940610690169

Bakker, A. B. (2009). Building engagement in the workplace. In R. J. Burke \& C. L. Cooper (Eds.), The peak performing organization (pp. 50-72). Oxon, UK: Routledge. http://dx.doi.org/10.4324/9780203971611.ch3

Chen, Z. X., \& Francesco, A. M. (2003). The relationship between the three components of commitment and employee performance in China. Journal of Vocational Behavior, 62(3), 490-510. http://dx.doi.org/10.1016/S0001-8791(02)00064-7

Chen, Z. X., Tsui, A. S., \& Farh, J. L. (2002). Loyalty to supervisor vs. organizational commitment: Relationships to employee performance. China J. Occup. Organ. Psychol., 75(3), 339-356. http://dx.doi.org/10.1348/096317902320369749

Colarelli, M. (1984). Methods of communication and mediating processes in realistic job previews. Journal of Applied Psychology, 69, 633-42. http://dx.doi.org/10.1037/0021-9010.69.4.633

Cropanzano \& Mitchell. (2005). Social exchange theory: an interdisciplinary review. Journal of Management, 31, 874-900. http://dx.doi.org/10.1177/0149206305279602

Diamond \& Allcorn. (1985). The cornerstone of Psycho-analytic Organizational Analysis. Journal of Organizational Behavior.

Eisenberger, R., Armeli, S., Rexwinkel, B., Lynch, B., \& Rhoades, L. (2001). Reciprocation of Perceived Organizational Support. Journal of Applied Psychology, 86(1), 42-51. http://dx.doi.org/10.1037/0021-9010.86.1.42

Eisenberger, R., Huntington, R., Hutchinson, S., \& Sowa, D. (1986). Perceived organizational support. Journal of Applied Psychology, 71, 500-507. http://dx.doi.org/10.1037/0021-9010.71.3.500

Fakeeh, M. (2009). Saudization as a Solution for Unemployment. The Case of Jeddah Western Region Submitted in Fulfillment of the requirements for the degree of Doctorate in Business Administration. University of Glasgow. Business School.

Flynn, F. J. (2003). How much should I give and how often? The effects of generosity and frequency of favor exchange on social status and productivity. Academy of Management Journal, 46, 539-553. http://dx.doi.org/10.2307/30040648

Goffman, E. (1961). Encounters: Two Studies in the Sociology of Interaction. Indianapolis: Bobbs-Merrill Co.

Hackman, J. R., \& Oldham, G. R. (1980). Work redesign as an approach to person-environment fit. Addison-Wesley, Reading, MA.

Hay Group Research. (2010). Saudi Arabia Press Release: Saudi Workers show strong work ethic 86\% Engaged in their current roles.

Kahn, W. A. (1992). To be full there psychological presence at work. Human Relations, 45, 321-49. http://dx.doi.org/10.1177/001872679204500402

Kahn's. (1990). Psychological conditions of personal engagement and disengagement at work. Academy of Management Journal, 33, 692-724. http://dx.doi.org/10.2307/256287

Kasim, R. (2012). Workforce Nationalization in the Gulf Cooperation Council States. Center for International and Regional Studies. GeorgeTown University, School of Foreign Service in Qatar.

Khan, W. (1990). Psychological conditions of personal engagement and disengagement at work. Academy of Management Journal, 33(4), 692-724. http://dx.doi.org/10.2307/256287

Koyuncu, M., Burke, R. J., \& Fiksenbaum, L. (2006). Work engagement among women managers and professionals in a Turkish bank: Potential antecedents and consequences. Equal Opportunities International, 25, 299-310. http://dx.doi.org/10.1108/02610150610706276

Langelaan, S., Bakker, A. B., Schaufeli, W. B., \& Van Doornen, L. J. P. (2006). Burnout and work engagement: Do individual differences make a difference? Personality and Individual Differences, 40, 521-532. http://dx.doi.org/10.1016/j.paid.2005.07.009 
Luthans, F. (2002). The need for and meaning of positive organizational behavior. Journal of Organizational Behavior, 26, 695-706. http://dx.doi.org/10.1002/job.165

Maslach, C., Schaufelli, W. B., \& Leither, M. P. (2001). Job Burnout. Annual Review of Psychology, 52, 397-422. http://dx.doi.org/10.1146/annurev.psych.52.1.397

Mauno, K. U., \& Ruokolainen, M. (2007). Job demands and resources as antecedents of work engagement: A longitudinal study. Journal of Organizational Behavior, 70, 149-171.

Orpen, C. (1994). The effects of exchange ideology on the relationship between perceived organizational support and job performance. Journal of Social Psychology, 134, 407-408. http://dx.doi.org/10.1080/00224545.1994.9711749

Pew Research Center. (2011). The Future of the Global Muslim Population: Projections for 2010-2013. Washington, DC: Pew Research Center.

Rath. \& Clifton. (2004). How Full Is Your Bucket? Positive Strategies for Work and Life. Rath, Tom, Clifton, Donald O. CIO Insight.

Rhodes, G., Halberstadt, J., \& Brajkovich, G. (2001). Generalization of mere effects in social stimuli. Soc. Cognition, 19, 57-70. http://dx.doi.org/10.1521/soco.19.1.57.18961

Robinson et al. (2004). The Drivers of Employee Engagement. Institute for Employment Studies, Brighton.

Rotherbard, N. P. (2001). Enriching or depleting? The dynamics of engagement in work and family roles. Administrative Science Quarterly, 46, 655-84. http://dx.doi.org/10.2307/3094827

Witt, L. A. (1992). Exchange ideology as a moderator of the relationships between importance of participation in decision making and job attitudes. Human Relations, 45, 73-85. http://dx.doi.org/10.1177/001872679204500104

Witt, L. A., \& Broach, D. (1993). Exchange ideology as a moderator of the procedural justice-satisfaction relationship. Journal of Social Psychology, 133(1), 97-103. http://dx.doi.org/10.1080/00224545.1993.9712122

Witt, L. A., Kacmar, K. M., \& Andrews, M. C. (2001). The interactive effects of procedural justice and exchange ideology on supervisor-rated commitment. Journal of Organizational Behavior, 22, 505-515. http://dx.doi.org/10.1002/job.99

\section{Copyrights}

Copyright for this article is retained by the author(s), with first publication rights granted to the journal.

This is an open-access article distributed under the terms and conditions of the Creative Commons Attribution license (http://creativecommons.org/licenses/by/3.0/). 